\title{
Anthropological measurement of the history of philosophy by Bertrand Russell ${ }^{\star}$
}

\author{
A.S. Kolesnikov \\ St. Petersburg State University, \\ 7-9, Universitetskaya nab., St. Petersburg, 199034, Russian Federation
}

For citation: Kolesnikov A. S. Anthropological measurement of the history of philosophy by Bertrand Russell. Vestnik of Saint Petersburg University. Philosophy and Conflict Studies, 2019, vol. 35, issue 2, pp. 264-272. https://doi.org/10.21638/spbu17.2019.203

This article examines anthropological preferences in historical and philosophical work of the English philosopher and mathematician, public figure and logician, Bertrand Russell. The intellectual history of this English philosopher is closely linked to interpretations of those thinkers who were his teachers and who made an important impact on the development of his conceptions: G. F. Stout, James Ward, F. Pollock, B. Spinoza, J. Moore, L. Wittgenstein, G. Peano, G. Frege, A. Meinong, F. Brentano, H. Sidgwick, J. Bentham, T. Hobbes, and S. Freud. Special attention is given to the influence of Spinoza's philosophy on Russell's conceptual formations. In article reveals the field of philosophy in the perspective of its author; how does he recognize historicist of philosophy affair matter, what values does he uphold and etc. Anthropological reduction is analyzed in the history of philosophy is an attempt to give explanation to science, arts, religion, with the help of man's culture and to understand human being on the basis of these formations, executed by him (science, culture, religion, arts). In the works Russell not only explains quite successfully all the philosopher was thinking of, but also the notions of what he, exactly thinks about each examined philosopher. All that contributed to Russell's creating the style of reflection which G. Ryle named "thoughtless experimentation".

Keywords: anthropological measurement, history of philosophy, G. F. Stout, J. Ward, F. Pollock, B. Spinoza, J. Moore, L. Wittgenstein.

Anthropological measurement of the history of philosophy should answer a number of questions. What is the field of philosophy from the perspective of its author? What does the history of philosophy rest upon? What does the author do, and how does she recognize her matter? What values does she uphold, and what are her personal interests and position in the history of philosophy? And so on. Anthropological reduction in the history of philosophy is an attempt to explain science, arts, and religion, with the help of culture and to understand the human being on the basis of these formations as executed by people (science, culture, religion, arts). Russell's measurement of the history of philosophy is along these lines. His treatment is far from established standards, but it attracted many people by his fame as a thinker and the accessibility of his writing. His History of Western Philosophy was a monumental survey, followed by the fresher volume Wisdom of the West.

* The research was undertaken with support by a grant from the Russian Scientific Foundation, no. 17-18-01440 "An anthropological measurement of the history of philosophy".

(c) Санкт-Петербургский государственный университет, 2019 
In both of these volumes and other essays, Russell not only explains quite successfully all he was thinking, but also the notions of what he thought exactly of each philosopher he examined. Historians of philosophy in the past were inclined to be more monotonous in formulating historical development. Russell's works are successful in showing that philosophizing can be both interesting and instructive for a mass audience.

Setting about to consider the works of philosophers of the past without philosophical premises is not only naïve, but also close to a positivist conception of cognitive activities by which a historian can restore the facts of historical reality. Critical philosophy of history dispensed with these illusions. The story of the history of philosophy means ceaseless work on the interpretation of fruitfulness carried out by the historians of philosophy. The very position of the philosopher depends upon the influence to which he was subjected. Russell pointed out that his outlook was formed under the influence of the ideas of four philosophers of the West: J.Moore, who freed himself from idealism and asserted that a fact did not depend on our cognition of the fact (it is not constructed by consciousness, as Kant considered, but is more or less dimly presented to our cognition); A. Whitehead, who upheld the principle of "Ockham's Razor" as "the highest maximum of scientific philosophizing"; W. James, who rejected dualism with the help of neutral monism; and L. Wittgenstein, who proclaimed that all logical truths are tautologies, and then set out to interpret the relation between language and facts $[1, \mathrm{p} .3]$. It is also worth mentioning that he was greatly influenced by his teachers: the Kantian James Ward, and Hegelians G. F. Stout and D.E. McTaggart, as well as G. Peano, G. Frege, A. Meinong, F. Brentano, H. Sidgwick, J.Bentham, T.Hobbes and S. Freud. Russell came to philosophy via mathematics and logic, but this does not belittle his interest in the history of philosophy. He read Mill, Kant, and Hegel, Bradley's Logic, Spinoza, Hume, and Descartes, and of course Moore. He studied profoundly Leibniz, James, Bergson, Dewey, and Santayana, about whom he wrote monographs and profound articles, as well Hegel's philosophy of history (1941). But his Weltanschauung was especially influenced by his visit to the International Congress on Philosophy in 1990. All this contributed to Russell's creating a style of reflection that G. Ryle called "thoughtless experimentation".

The history of philosophy is written by the philosopher with an historical inclination or feeling the necessity of reflecting and from time to time aiming to demonstrate his point of view. Russell did just this in his history of philosophy. During his studies at Trinity College in 1893-94, Russell attended several courses on philosophy. These includedlectures by G. F. Stout and James Ward on the history of philosophy". He took careful notes that proved useful when he later wrote his philosophical portraits of various Western philosophers. Georg Frederik Stout (1860-1944), the publisher and editor of Mind (1891-1921), was a specialist in philosophical psychology and the author of a book on psychology. His own teacher James Ward (1843-1925) was an idealist and also wrote on psychology. None of them published general works on the history of philosophy, although Ward wrote on Kant, And Stout devoted two lectures to Spinoza in January 1894, six lectures on Hobbes, and nine on Descartes. Ward devoted part of one lecture to Spinoza in his review from Descartes and up to Reid and Spencer. Generally speaking, Stout embedded Spinoza in philosophical psychology, attributing much really to Hobbes, while Ward explored his metaphysics. Spinoza's ethics were neglected by Henry Sidgwick in his two lectures on which Russell took partial notes. Stout concentrated his attention mainly on Spinoza's theory of Man. He attached great importance to the inducement of self-preservation and 
to his attitude to Man's power, liberty, and perfection. Stout told his students how it was possible to calculate the fact that Spinoza and Hobbes divided one and the same purpose of cognizing Man's passions.

Though Russell then was inclined to monistic idealism, here he supported his late atomism that he upheld not only in metaphysics, but also in political philosophy. Liberal, atomistic, individualistic outlook of man in society demands psychological confidence and esteem for every person with autonomous activity. However, Stout, in the monistic spirit of the times, proposed a criticism of the atomistic outlook on man. He told his audience in his first lecture: "Someone's opinion just like an individual, pretending to share all the essence, is condemned to failure, so far as he inherits the essence of the thing, which is not he himself" [2, p. 129]. Stout emphasized Spinoza's concept of power, believing that power gives joy and that is the equivalent of liberty and perfection [2, p. 131]. "We are free, because all that happens to us, is created by ourselves" - this was typical statement of the authors, upholding the negative doctrine of liberty and concentrating on the absence of external warning. Stout also discussed the notions of some passions and attacked Spinoza on the concept of will. When discussing Hobbes' world outlook, they introduced themselves as important precursors of deterministic psychology of Spinoza. Stout touched on Spinoza's ethical and even religious questions. He considered Spinoza a relativist, and in certain passages he explained the ordinary usage of "good" and "evil" (although he did not call this "relativism"); he maintained, controversially, that Spinoza could allow something absolute in making distinctions between good and evil [2, p. 127].

Russell's synopses included his regard for Spinoza. This influence on own world outlook appeared to be long and constant. First, Stout in his lectures quoted Pollock; Russell read Pollock himself and 17 years later recommended that book to others. Second, Ward began his lectures by telling his audience how to read Spinoza's The Ethics: "Read The Ethics, long commentaries, prefaces, digressions, boring sentences". If Ward said that the sentences and judgments were boring, what did he mean by this? He may have shared Stout's views. He noted that interest in Spinoza did not die. Russell wrote in his History of Western Philosophy that detailed showing is not the merit of mastership; he maintained that commentaries contain all the best in The Ethics [3, p. 572, 554].

The third, similar judgment by Russell, that Spinoza's metaphysics is inconsistent, is also contained in Ward's lectures. According to Ward, Spinoza's world outlook disintegrated into the following components: his rationalistic, geometrical method was denounced by Kant as insolvent, although mathematics is accomplished to a considerable degree "by the use of clearing up mathematical intuition", while philosophy cannot be intuitive; his mathematical model loses validity in its judgment of causality (as "cause" becomes equivalent to "logical condition"); and the distance between finite and infinite modifications of the attribute cannot be crossed. As for Spinoza's concept of God, Ward believed, that he was only a means, and nowadays a means "Absolute or certainty". Ward held that the church had prohibited works by Spinoza before the first edition of Kant, i.e. before the publication of The Critique of Pure Reason in 1781, which made Kant historically more influential. When speaking on Spinoza's pantheism and his impact on Hegel, he noted that "Erdmann is better than Spinoza". Ward closed his lecture as follows: "In the first hint of his doctrine there are two aspects. The denial of free will, but it's not worth using freedom as a synonym to necessity as there is much insidiousness. God creates things in case of inborn necessity of his own nature which at the same time acts as freedom". To create 
knowledge there is only the Cartesian principle of clarity and definition. Thus, Ward influenced Russell's comprehension of Spinoza, from the point of view of classifying Spinoza as a mere absolute idealist.

Russell read not only Pollock's book, but, and evidently earlier, Erdmann's History (1874), which by explaining the attributes of thought took great interest in Spinoza's political philosophy. While explaining moral philosophy, Erdmann united evaluations of Spinoza's doctrine in the field of freedom, will, and knowledge. Russell also noted passages touching on three kinds of Spinoza's knowledge: sensation or opinion, faculty of reasoning, and intuition. Spinoza hoped that one who realizes the necessity of tying together the ends of the things does not turn to will, which is present in some other relations. Even from his acquaintance with Spinoza, Russell had a rather high opinion of Spinoza's psychology. He wrote to Alice Smith, "I was reading Hobbes and Spinoza and in the morning I began to read Descartes on the subject of passion; Spinoza is smart..." Much later Russell denied the intellectual love of God in Spinoza's normative ethics.

In any event, the well-known lawyer jurist Frederick Pollock (1845-1937) wrote reviews on Spinoza's works for popular magazines, as well as a short book, Spinoza, His Life and Philosophy (1880). It is not known whether Russell read Pollock's shorter articles, but as we have seen he respected his critical book on Spinoza. He wrote to his friends in 1902: "Yes, Spinoza text is hard. I quite insistently advise you first to read the book by Pollock about him; there you will find out how much easier it is to penetrate into Spinoza's heart". He wrote to Lady Ottoline Morrell: "Don't worry about reading Spinoza, it's not time yet!.. If you have some time to spare, you a better read Pollock first, instead of reading Spinoza himself $[4$, p. 87].

A more important effect that Pollock produced on Russell was inspiring him to admire Spinoza. Thus, he wrote to Lady Ottoline (no. 169a, August 11): "Since I have been reading the book by Pollock, since the time of my being a final student, writing my diploma-paper Spinoza has been one of the most important people in my inner world". Pollock's book included an excellent set of quotations from Spinoza, and Russell's advice to Alice on reading Pollock was undoubtedly based on his wide studying, his being multilingual, his knowledge of history and of philosophers of the past and of discoveries in science. Moreover, he followed Green's explaining Spinoza's monistic idealism. At the same time, Russell was inclined to asceticism; Pollock wrote of "next-to incredible thrift of his health and economy" [4, p.41]. Russell always criticized the church, and Spinoza was the right man for him in this respect as well.

Further, regarding Goethe's interest in Spinoza, Pollock cited a passage that seemed glued to Russell's reasoning. This is a passage where Goethe quoted Spinoza (ESP19): "He who loves God cannot endeavor that God will love him in return" [3, p. 395]. Later, Russell came back to Goethe, for he considered the passage misunderstood. In 1910, in his review for White and Sterling on the translation of Ethics, Russell mainly referred to "pedantic praising" by Goethe. However, at the time publication of History of Western Philosophy, Russell still recollected and reread him: "Goethe, who praises Spinoza, without even trying to understand him, thought this proposition as an instance of self-abnegation. There is nothing of the sort of similar but a logical consequence of Spinoza's metaphysics. He does not say that man ought not to want God to love him; he says that man who loves God cannot want God to love him" [3, p. 576, 558]. Russell corrected the wordy protest in his translation. It is possible to read all of this in a detailed book by K. Blackwell, The 
Spinozistic Ethic of Bertrand Russell (1985) [5]. Russell called for disjoining Spinoza's ethics from metaphysics even when treating him critically. He considered the latter one "the best examples" of "logical monism."

After of Russell's History of Western Philosophy had appeared, it repeatedly was a target of critical analysis. V.V.Sokolov was one of the first domestic philosophers who devoted an article to this book. Following the atmosphere of criticism, the thinker as a bourgeois idealist, who inherits "bourgeois prejudices in the history of philosophy and culture" [6, p. 100], exhibits western centrism, incomprehension of Marxism, reducing historical materialism to economical materialism, and the impact of epistemology of Marxism on Russel's theory of cognition. On the other hand, there were positive sides to his work: the close connection between philosophy and science is revealed; as a staunch supporter of relativism he criticized religious mythological views. This also affected the negative characteristics of representatives of objective idealism (Socrates, Plato, Thomas Aquinas, Hegel), and of subjectivism, mistakes of which resulted from attempts to ignore all the facts out of man. He did not consider his view to be idealistic, as he classified all philosophical systems either according to "the method" (empirical and a priori ones) or "according to by their results" (realistic and idealist) [3, p. 799]. In this sense he qualified his position as empirical and realistic.

As for the philosophers of the past, Russell held the highest opinion of Hume, thinking his philosophy to be "a modern form of nominalism" [3, p.680], so far as here was the beginning of "modern philosophy of causality" [3, p. 683] and because he "finally" banished the notion of substance from philosophy. Russell distinguished "logical positivism" from "analytical empiricism" of Locke, Berkley, and Hume, and modern analytical empiricism "includes mathematics and develops powerful logical technique" [3, p. 841]. Russell as a neorealist sought, theoretically, - to widen the scope of empiricism so that it could correspond to the practice of the cognition in the world. S. Radhakrishnan thinks that "Since Socrates' notion the general and up to Russell's mathematical logic the History of Western Thought was presented itself as an excellent illustration for the primacy of logical beginning" [7, p. 133].

Russell maintains that all historic-philosophical methodologies proceed from deductive- mathematical (Pythagoras, Plato, Thomas Aquinas, Spinoza, Kant) and inductiveempirical approaches (Democritus, Aristotle, Locke and all empiricists of the contemporary time). The methodology of "logical analysis" can reconcile these contradictory views, eliminating a Pythagorean from mathematical principles and connecting "empiricism and personal interest in deductive parts of human mind" [3, p. 836]. The means that logical syntax of a language as a scientific mode of solving philosophical problems is banished from the philosophy of "metaphysics." Russell constantly showed agnosticism, skepticism, and the persuasion that philosophy can't prove or disprove the truth of religious dogma, so far as it is an intermediate sphere between theology and science [3, p. 842]. Religion, philosophy, and science ensure balance, which promotes Russell's identifying materialism and mechanical philosophy. While he did not consider the materialist lines of Holbach, Diderot, Feuerbach, Gassendi, Priestly, Toland, and Bacon, he did not investigate the conceptions of Campanella, Bruno, or Telesio, and as for Hobbes, and he passed him for a "political philosopher." History of Philosophy itself is written on the basis of other similar texts. Thus, antiquity in the social-historical aspect is written by Rostovtzeff, F. Cornforth, Burnett, and Biven. It is beyond question that the opinions of the enumerated authors are 
original, but Russell trusts them unreservedly. His division into periods is schematic and uncorrected. History of Philosophy separates some systems of the most important thinkers against a back-ground of all of the rest. And this gallery of personalities is represented with some preconceptions, which has already become ordinary in the history of Western philosophy. It is often narration, but not elucidating the problems and essence of phenomena.

The thinker perceives solving the most important problems of philosophy: problems of social being in the philosophy of Eleatics; theories of Plato's ideas as universalities; problems of the general and the single in Aristotle; problems of cogito in Descartes; of metaphysical monism in Spinoza; problems of the general and the single in Hegel - Russel perceived all these as the only concepts he shared in the concept of logical syntax of a language which he regards as the only true one. Russell's conviction of the possibility of working the method of logical analysis of a language as only scientific logic leads to ignoring such thinkers as Fichte and Schelling and to extreme subjectivism when studying such a thinker as Kant. According to Russell, philosophy - as history demonstrates it - has always been engaged in logic and theories concerning nature, and also in ethical and political problems. For all that, Russell is unhistorical. When addressing ethical and political theories, Russell usually used modernizations and unacceptable analogies. Ironically, Russell himself condemned historians of philosophy and the erroneous method of "entire interpretation" of studied thinkers, in the light of the following development of philosophical thought [3, p. 490]. Analogies between earlier and later thinkers come to obliterating real historical borders, to the modernization of philosophical studies of the past. Thus, Russell considers some traits to be branches of Heraclitus' ethics and reminding him of Nietzschean pattern [3, p. 61]. He stressed Plato's "communism" [3, p. 131 et al.], compared Diogenes' Cynic with Rousseau and Tolstoy [3, p. 251], compared Augustine to Tolstoy [3, p.360] and Epicure - to Bonham's utilitarianism [3, p. 263], and Epicure's "indeterminism" to the indeterminism of Eddington [3, p.265], and so on.

Russell says frankly that he does not understand what the word "category" means in Aristotle, Kant, and Hegel [3, p.210]. The concept of essence is a "notion, hopelessly bewildering," because the question about essence is purely linguistic: a word can have an essence, but a thing cannot [3, p. 222]. The notion of dialectics is used when working in the traditional Aristotelean-scholastic sense of a purely wordy discussion of philosophical questions, which does not adequately address the truth of necessary premises. For Russell the truth of common sense, a philosophical truth, consists of logical conclusions; a scientific truth is a result of a physical experiment, and a mystical, religious truth is capable of penetrating into the mysteries of the human being and undiscovered wonders. The crisis of the principles of modern foreign gnosiology quite naturally finds its reflection in the crisis of the problem of the truth as its central problem. In such a case, "the truth is an objective uncertainly, induced by the most passionate inner conviction" (Kierkegaard), i. e. the more subjective the truth is, the more sincere it is. And so far as "we can't stop up believing" and "no belief whatever can be founded on reason" [3, p. 690-691], then there is no truth, but there is belief.

That is how the influence of Hume-like and Leibnitz-like analytical a priorism and aspiration for the cognition of "logical trustworthiness" that can't be achieved, but should be believed in, becomes apparent. This approach to truth is purely formal; it is made absolute because of the lack of induction. Such formalism is overcome by way of the criterion 
of practice. However, the influence of the dualism of experience and logic, giving birth to factual-empirical and formally-logical knowledge, is much more. These levels of knowledge correspond to logical truth (coordination, non-contradictoriness of knowledge) and factual truth (correspondence of proposals with empirical facts). Here the correspondence of this dualism with the division of the knowledge in Leibnitz, into the truth of reason and truths of the fact, is seen more legibly. The division of judgements into analytical and synthetic ones, just as for Leibnitz, is considered a logical sign of distinction between factualistic and formal knowledge (in more detail see: [8; 9]).

On other hand, the principles of methodology of historical and philosophical investigation sometimes brings Russell to realize the real genesis of society and the social significance of some philosophical conceptions before putting the question about their class conditionality and class destination. However, it is sooner an exclusion than a rule. Of course Russell's methodology is ideological, as in the majority of cases it ascribes to philosophy and other spiritual factors a decisive influence on "life." For example, Russell connects the property and wealth of the church in the Middle Ages, and its triumph over secular power, with the fact that "majority of people, including greater part of secular rulers themselves" [3, p. 318] were profoundly convinced of the veritability of its dogma. The struggle in the slave-owning society as a matter of fact is not explained by Russell, which was a defining factor in ancient philosophy, carrying the center of gravity of philosophical interests from naturalism over ethics, which appeared together with Socrates and continued developing after him, or growth of subjectivism and mysticism at the end of history of ancient philosophy.

The individual activity of geniuses of philosophical thought, long fixed in the spirit of established Western historic-philosophical traditions, is almost exclusively defined while considering the history of philosophy. The absence of division into periods of historicphilosophical process, which could be supported by objective facts and peculiarities of socio-economic development, brought claims to diffused characteristics and definition that sometimes were highly important. Russell's explanations of the social function of philosophical ideas are typically idealist. "The rebellion of individualistic instincts against social bonds is a key to understanding philosophy, politics and feelings" [3, p. 699]. In accordance with this, the struggle between philosophical schools becomes extremely narrow and simplified, so far as "over a long period of time starting from the VI century B. C. and up to nowadays, philosophers were divided into those, who longed for strengthening social ties and those who wanted to weaken them" [3, p. 16]. Coming to the end of History of Western Philosophy, Russell was convinced that "the habit of careful truthfulness, acquired in the practice of this philosophical method (empirical and logical) can be extended over all the spheres of human activities. It will bring, wherever it exists, to decreasing fanaticism, to the increasing capacity to sympathizing with same body and mutual understanding. Abandoning part of its dogmatic pretensions philosophy does not cease to offer and inspire this or that way of life" [3, p. 843]. One of most essential functions of philosophy with respect to personality, "facing the horror of cosmic solitude," lies in the fact that the function of philosophy is capable "of teaching how to live without confidence and at the same lime not being paralyzed because of indecision" [3, p. 8-9]. In any case, we must correct how Russell, and before him Fung Yu-lan, and then Jaspers, Abbagnano, Glockner, Tomlin, Reihenbach, Kopleston, Bohensky, Radhakrishnan, and others, offered a new view of the history of philosophy. Like Giovanni Santinello, the author was using 
compositions of (as many as) 160 historians of philosophy to present a philosophy created by thinkers for ages.

\section{References}

1. Eames, E. R. (1972), "Russell about 'What there is", in Revue internationale de philosophie, no. 102, pp. 483-498.

2. Russell, B. (1988-1899), The Collected Papers of Bertrand Russell, vol. I, in Cambridge Essays, ed. K. Blackwell, A. Brink, N. Griffin, R. Rempel, and J. Slater, Allen \& Unwin, London, UK.

3. Russell, B. (1959), Istoriia zapadnoi filosofii [History of Western Philosophy and its connection with Political and Social circumstances from the Earliest Times to the Present Day, Izdatel'stvo inostrannoi literatury Publ., Moscow, Russia. (In Russian)

4. Griffin, N. (2002), The Selected Letters of Bertrand Russell: The Private Years, 1884-1914, Routledge, London, UK.

5. Blackwell, K. (1985), The Spinozistic Ethic of Bertrand Russell, pt. 2. Early period (1883-1901), Allen \& Unwin, London, UK.

6. Sokolov, V. V. (1960), "B. Russell kak istorik filosofii” [B. Russell as historian of philosophy], in Voprosy filosofi, no. 9, pp. 100-110. (In Russian)

7. Radhakrishnan, S. (1937), Idealist View of life, Allen \& Unwin, London.

8. Korneeva, A.I. (1962), Kritika neopozitivistskikh vzgliadov na prirodu poznaniia [Criticism of neopositivistic views of the knowledge nature], Izdatel'stvo VPSh i AON Publ., Moscow URSS. (In Russian)

9. Tevzadze, G. S. (1971), Kritika empiristskogo ponimaniia istiny i teorii poznaniia B. Rassela [Criticism of empirical understanding of the truth and theory of knowledge B. Russell], Abstract of the dissertation, Tbilisi, URSS. (In Russian)

Received: August 10, 2018

Accepted: February 7, 2019

Author's information:

Anatoly S. Kolesnikov — Dr. Sci. in Philosophy, Professor; kolesnikov1940@yandex.ru

\section{Антропологическое измерение истории философии Бертрана Рассела}

\section{А. С. Колесников}

Санкт-Петербургский государственный университет,

Российская Федерация, 199034, Санкт-Петербург, Университетская наб., 7-9

Для цитирования: Kolesnikov A.S. Anthropological measurement of the history of philosophy by Bertrand Russell // Вестник Санкт-Петербургского университета. Философия и конфликтология. 2019. Т. 35. Вып. 2. С. 264-272. https://doi.org/10.21638/spbu17.2019.203 (In English)

В статье рассматриваются антропологические предпочтения в историко-философском творчестве английского философа и математика, общественного деятеля и логика Бертрана Рассела. История философии для английского философа - это непрекращающаяся работа над интерпретацией тех мыслителей, которые были его учителями, с которыми он работал, у которых он учился, которые оказали существенное влияние на выработку его концептуальных решений. Среди этих мыслителей Г. Ф. Стаут, У.Джеймс, Ф. Поллок, Б.Спиноза, Дж. Мур, Л.Витгенштейн. Известно также влияние Дж. Пеано,

* Исследование выполнено при поддержке гранта Российского научного фонда, проект № 17-18-01440 «Антропологическое измерение истории философии». 
Г. Фреге, А. Мейнонга, Ф.Брентано, Г. Сиджвика, И. Бентама, Т. Гоббса и 3. Фрейда. Рассел пришел к философии через математику и логику, но это не умаляет его интереса к истории философии. Определяющим при рассмотрении истории философии остается почти исключительно индивидуальная деятельность гениев философской мысли, распределенных в духе давно установившейся в западной историко-философской традиции. Особое внимание уделено воздействию философии Спинозы на концептуальные решения Рассела. В статье раскрывается поле истории философии в перспективе ее актора; как осознает свое дело историк философии; какие ценности он отстаивает и т. д. Анализируется антропологическая редукция истории философии, когда есть попытка объяснить науку, искусство, религию, культурой человека и понять человека из этих произведенных им формаций (науки, культуры, религии, искусства). В своих работах Рассел не только разъясняет идеи рассматриваемых философов, но и высказывает собственное мнение о них. Все это способствовало тому, что Рассел создал стиль размышления, который Г. Райль назвал «необдуманным экспериментированием».

Ключевые слова: антропологическое измерение, история философии, Г.Ф.Стаут, Дж. Уорд, Ф. Поллок, Б. Спиноза, Дж. Мур, Л. Витгенштейн.

Статья поступила в редакцию 10 августа 2018 г;; рекомендована в печать 7 февраля 2019 г.

Контактная информация:

Колесников Анатолий Сергеевич — д-р филос. наук, проф.; kolesnikov1940@yandex.ru 